\title{
Searching historical herbal texts for potential new drugs
}

Eric J Buenz, Brent A Bauer, Holly E Johnson, Gaugau Tavana, Eric M Beekman, Kristi L Frank, Charles L Howe

Complementary and Integrative Medicine Program, Mayo Clinic College of Medicine, Rochester, MN 55905, USA Eric J Buenz ethnobotanist

Brent A Bauer director,

complementary and integrative medicine programme

Kristi L Frank graduate student Charles L Howe doctor of infectious diseases

Institute for Ethnomedicine,

National Tropical Botanical Gardens, Kalaheo, HI, USA

Holly E Johnson

botanist

Gaugau Tavana botanist

University of Massachusetts, Amherst, MA, USA Eric M Beekman professor of Germanic languages

Correspondence to: E J Buenz

buenz@

biosciential.com

BMJ 2006;333:1314-5 National Tropical Botanical Gardens, Kalaheo, Hawaii, USA. To verify that we had collected the same plant as that described by Rumphius, we compared voucher specimens with original plates from the Rumphius text (courtesy of the Wangensteen Historical Library, University of Minnesota, Minneapolis, USA).

\section{Laboratory confirmation of the antibacterial properties}

We preserved the leaves and kernels of A racemosa collected in the Independent State of Samoa in 70\% ethanol and prepared alcohol extracts according to standard protocol. Various concentrations of kernel extract and leaf extract were added to samples of two Gram positive bacteria (Staphylococcus aureus and Enterococcus faecalis) and two Gram negative bacteria (Pseu-

Minimal inhibitory concentrations $(\mu \mathrm{g} / \mathrm{ml})$ of extracts of the atun tree (Atuna racemosa)

\begin{tabular}{lccccc} 
& \multicolumn{2}{c}{ Gram positive bacteria } & & \multicolumn{2}{c}{ Gram negative bacteria } \\
\cline { 2 - 3 } \cline { 6 - 7 } Extract & $\begin{array}{c}\text { Staphylococcus } \\
\text { aureus }\end{array}$ & $\begin{array}{c}\text { Enterococcus } \\
\text { faecalis }\end{array}$ & & $\begin{array}{c}\text { Pseudomonas } \\
\text { aeruginosa }\end{array}$ & Escherichia coli \\
\hline Leaf & $75-100$ & $175-225$ & & $>1000$ & $>1000$ \\
\hline Kernel & $30-35$ & $25-30$ & & $>1000$ & $>1000$ \\
\hline
\end{tabular}

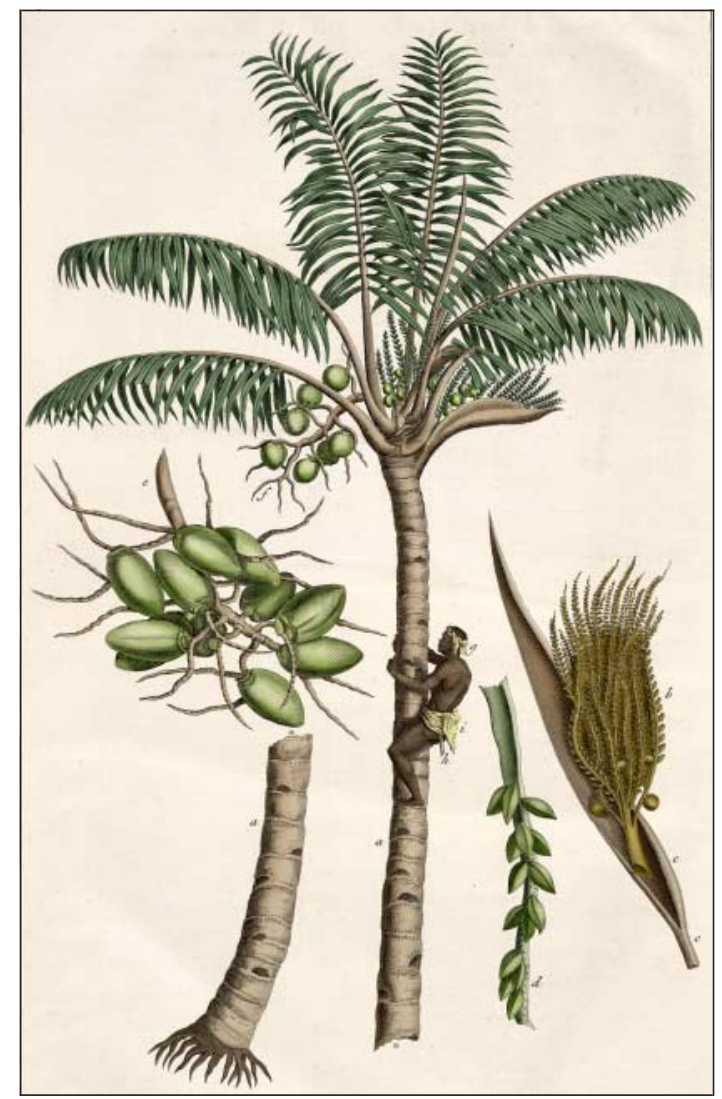

Fig 1 Images from the original Ambonese Herbal written by Rumphius in the 1600s, which describes how kernels from the atun tree (Atuna racemosa) can be used to treat dysentery

domonas aeruginosa and Escherichia coli) in a minimal inhibitory concentration assay. This assay was performed in cation adjusted Mueller-Hinton broth according to the standard protocol. ${ }^{5}$

The assay showed that the extracts from $A$ racemosa (the atun tree described by Rumphius) had antibacterial activity that was specific for the Gram positive bacteria tested (table). The minimal inhibitory concentrations of the leaf extract were significantly different from those of the kernel extract in both of the Gram positive bacteria ( $S$ aureus 75-100 $v$ 30-35 for the leaf and kernel; E faecalis 175-225 v 25-30; $\mathrm{P}<0.05$; MannWhitney rank sum test). The kernel had a stronger antibacterial effect, which corroborates Rumphius's reports of its use as an antibacterial agent. The minimal inhibitory concentration of kernel extracts for $E$ faecalis $(25-30 \mu \mathrm{g} / \mathrm{ml})$ is similar to other antibacterial compounds, such as carbenicillin (16-64 $\mu \mathrm{g} / \mathrm{ml})$.

\section{Implications}

Our findings show that potential drugs can be identified by searching historical herbal texts. Although we will never know the exact disorder that 
was treated with the kernel of the atun tree, these kernels were described nearly 400 years ago as a treatment for symptoms that are treated today with modern antibiotics. The current literature has no descriptions of the use of the atun tree to treat any disease similar to dysentery. ${ }^{6}$ By searching historical texts on herbal medicine, therefore, we have identified a potential new drug with antibacterial properties and have recovered lost knowledge of traditional medicine.

We thank Timothy Motley, Old Dominion University, USA for suggesting Independent Samoa as the location for the botanical expedition and Robin Patel, Mayo Clinic, USA for providing the bacterial samples.

Contributors and sources: EJB conceived the study, drafted the manuscript, and helped in its design and coordination. $\mathrm{BAB}$ helped design and coordinate the study. HEJ and GT helped in the botanical field work and creation of the voucher specimens. EMB translated the historical text and helped draft the manuscript. KLF assisted with the minimal inhibitory concentration assays. CLH helped in study design and statistical analyses. All authors read and approved the final manuscript. EJB is guarantor.

Funding: None.

Competing interests: Since this manuscript was accepted, Mayo Clinic has applied to patent the antibacterial properties of the atun tree. $\mathrm{BAB}$ and $\mathrm{EJB}$ are on the patent. The patent was only recently submitted so we do not know its status.

1 Riddle JM. History as a tool in identifying "new" old drugs. Adv Exp Med Biol 2002;505:89-94.

2 Buenz EJ, Schnepple DJ, Bauer BA, Elkin PL, Riddle JM, Motley TJ. Techniques: bioprospecting historical herbal texts by hunting for new leads in old tomes. Trends Pharmacol Sci 2004;25:494-8.

3 Buenz EJ, Johnson HE, Beekman EM, Motley TJ, Bauer BA. Bioprospecting Rumphius's Ambonese herbal: volume I. J Ethnopharmacol 2005:96:57-70.

4 Rumphius G. Herbarium amboinense. Amsterdam: Uytwerf, 1741-55.

5 National Committee for Clinical Laboratory Standards. Methods for dilution antimicrobial susceptibility tests for bacteria that grow aerobically. 6 th ed. Wayne, PA: NCCLS, 2003.

6 Prance G. The uses of Atuna racemosa Raf. (Chrysobalanaceae) in Samoa. Econ Bot 2004;58:470-5

(Accepted 10 March 2006)

doi 10.1136/bmj.39008.492361.BE

\section{The life of G E Rumphius}

Georg Everhard Rumpf (fig 2)-who Latinised his name to "Rumphius" after he achieved renown as a naturalist-enlisted as a soldier in 1652 with the first multinational corporation of the modern era, the Dutch East India Company. In 1657 Rumphius was discharged from the military to the civilian branch of the company, and he started to collect, describe, and draw the plants for his monumental Ambonese Herbal.

It is amazing that Rumphius's work was ever published. In 1670 he went blind, and four years later his wife and daughter were killed in an earthquake. Thirteen years later, in 1687, a fire levelled the capital of Ambon's European quarter, and his manuscripts and the botanical illustrations that he had drawn himself were burnt. Yet Rumphius took this opportunity to begin the herbal again; he dictated a new and revised text in Dutch to scribes, and he commissioned draftsmen to do the illustrations.

Finally, in 1692, the first half of the Ambonese Herbal was finished, and the governor general at the time ordered the manuscript and the illustrations to be copied. This order was fortunate, as the original herbal text was destroyed on the way to Holland when the transport ship was sunk by a hostile French naval squadron. Again, upon notification of the disaster Rumphius did not surrender to despair. Rather, he took the opportunity to augment and correct the first half of his text while he completed the six volumes of the second half. Rumphius added new material (to make volume seven) only a few months before his death at the age of 74 .

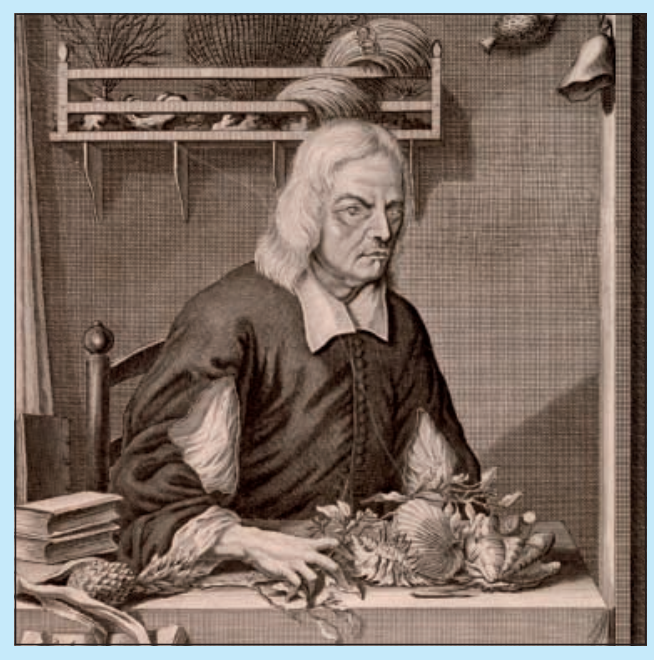

Fig 2 G E Rumphius, who spent most of his life documenting the medicinal uses of plants on the island of Ambon in Indonesia

\title{
Getting new drugs to market: how individuals could do this without leaving their desks
}

\author{
Joe Collier
}

At one time, all of the products that came out of a pharmaceutical company were researched, devised, developed, and manufactured within its four walls; the company offered the complete package. Now, although vast amounts of money, intellectual property, and management capacity remain within the imposing headquarters of the multinationals, much of the real work is done elsewhere-by start-up companies, contract houses, university departments, and public bodies.

One way or another, the work of big drug companies has changed, and inevitably this change, which will continue and probably accelerate, will lead to the collapse of the monolithic system and its replacement by smaller, leaner, and more nimble companies. As this process continues, virtual companies, run by individuals working from their desks in cyberspace, could well develop.

\section{Developing drugs}

The development of medicines for human use is a tricky business and one that is continually evolving as new technologies, such as genetic engineering, emerge. At its simplest, the process involves finding "new" molecules, purifying them, checking that they do what they are designed to do, showing that they work in 